Ann. Zootech., 1980, 29, no h. s., 127-143.

\title{
Utilisation of feed energy by growing ruminants
}

\author{
M. VERMOREL* and H. BICKEL** \\ *Laboratoire d'Etude du Métabolisme Energétique, \\ Centre de Recherches de Clermont-Ferrand, I.N.R.A., \\ Theix, 63110 Beaumont (France), \\ **: Institut für Tierernährung, \\ ETH, Universitätsstrasse 2, 8006 Zurich (Switzerland)
}

\begin{abstract}
As the energy value of feeds for growing ruminants is generally calculated from the data obtained from adult sheep, the various factors which can alter the utilisation of feed energy are considered :

- effects of species, age, diet composition and feeding level on energy digestibility and metabolisability, methane and urinary energy losses ;

- effects of age, breed, diet composition and feeding level on partial efficiency of metabolisable energy (ME) for maintenance or tissue gain and on overall efficiency of $\mathrm{ME}$ for growth.
\end{abstract}

\section{Résumé}

\section{Utilisation de l'énergie par les ruminants en croissance}

La valeur énergétique des aliments destinés aux ruminants en croissance étant généralement calculée à partir des données obtenues sur des moutons adultes, les auteurs examinent les facteurs susceptibles de modifier l'utilisation de l'énergie des aliments :

- effets de l'espèce, de l'âge, de la composition de la ration et du niveau d'alimentation sur la digestibilité de l'énergie, les pertes sous forme de méthane et dans l'urine et la teneur en énergie métabolisable (EM) de la ration ;

- effets de l'âge, de la race, du sexe, de la composition de la ration et du niveau d'alimentation sur l'utilisation partielle de l'EM pour l'entretien ou le gain d'énergie et sur l'utilisation globale de l'EM pour la croissance. 


\section{Introduction}

The energy value of feeds for growing ruminants is generally calculated from the data on digestive and metabolic energy utilization obtained on adult ruminants, mainly sheep. Due to the likely variations of ME efficiency with body gain composition, each feed is supposed to have several net energy values. However, if one assumes that these variations are similar for the various feeds, their energy values related to that of a reference feed (e.g. barley, as used in the Feed Unit system) are the same whatever the body gain composition. This assumption is open to discussion and, therefore, it is important to compare the digestive and metabolic utilization of feed energy in growing and adult ruminants and to analyse the effects of the various factors which can affect it. For practical purposes, the total efficiency of ME utilisation for growth must also be considered, in order to explain the variation in the feed conversion ratio with breed, sex, diet composition and feeding level.

\section{1. - Energy digestibility and metabolisability}

\section{A) Energy digestibility}

Only a few direct comparisons have been made of the energy digestibility (dE) of the same feeds or diets fed to growing and adult ruminants. Furthermore, the results have not always been published in detail and part of the information is not available. Therefore, precise and definitive conclusions still cannot be drawn. However, energy digestibility seems to be somewhat lower in growing ruminants than in adults, for the same feeding level, but the differences seem to depend on animal species (adult sheep versus lamb or growing cattle) and diet composition.

In growing lambs, $\mathrm{dE}$ is lower than in adult sheep (Figure 1A). The difference is only 1 or 2 per cent units for green forage or hays, but it amounts to 3 or 5 per cent units for concentrate diets (RAYMOND et al., 1954 ; BouvIER and VERMOREL, 1975 ; VERMOREL et al., 1980). In growing cattle, dE seems to be similar to or slightly higher than in adult sheep in the case of green forages, grass silages, hays and low concentrate diets (Figure 1B) (VAN DER Noot, 1954 ; Preston et al., 1957 ; Geay et al., 1976 ; Le Neindre, 1980), but generally lower in the case of maize silage and high concentrate diets (VAN DER NoOT, 1954 ; Colovos et al., 1970 ; Geay et al., 1978 ; CARle et al., 1980). According to JENTSCH et al. (1976), the discrepancy was on average 4.6 per cent units (that is about 3 per cent units after correction for the difference in feeding level) in the case of 44 diets containing about 70 per cent concentrate $(\mathrm{dE}=.78$ in adult sheep) fed to growing cattle and adult sheep and it did not vary significantly with cattle age.

In growing as in adult ruminants, $\mathrm{dE}$ decreases when the feeding level (L) increases, but the variations are not known accurately as the differences in feeding level $(\Delta L)$ are often small. The reduction in $\mathrm{dE}$ is about from 0 to 2 per cent units per multiple of the maintenance requirement $(\Delta L=1)$ for long grass or hays (Thomson and CAMmell, 1979 ; CARle et al., 1980) but from 4 to 8 per cent units for pelleted forages (BOUVIER and VERMOREL, 1975 ; Thomson and Cammell, $1979 ; 1980$; Vermorel et al., 1980) (Figure 2). It 

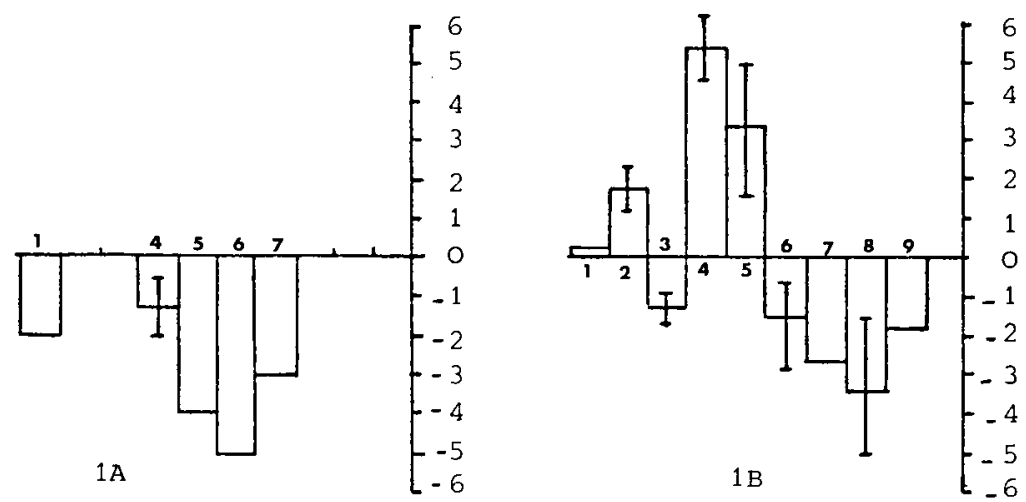

FIG. 1. - Difference in energy digestibility (percent units $d \mathrm{E}$ )

between lamb and adult sheep (1 A) and growing cattle and adult sheep (1B)

$1=$ grass; 2 = grass silage;

$4=$ hay (chopped or pelleted);

$6=$ hay +50 p. 100 concentrate;

8 = maize silage;

$10=$ maize silage +50 p. 100 concentrate.
$3=$ grass silage +30 p. 100 concentrate

$5=$ hay +30 p. 100 concentrate;

$7=$ hay +85 p. 100 concentrate;

$9=$ maize silage +30 p. 100 concentrate

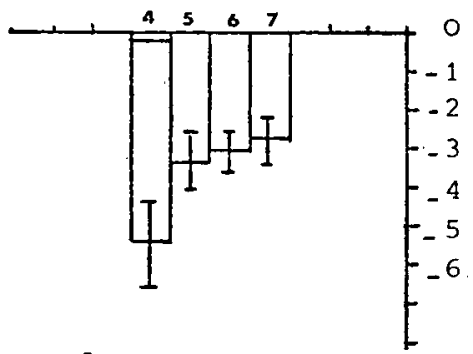

$2 \mathrm{~A}$

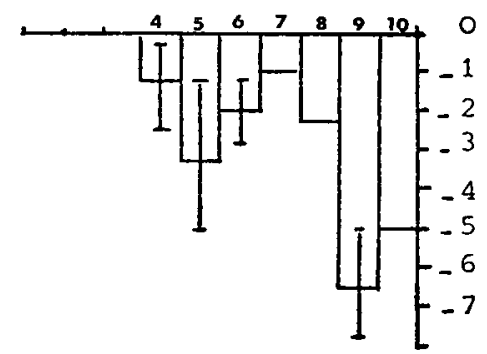

$2 \mathrm{~B}$

FIG. 2. - Variation in energy digestibility with feeding level (percent units $d \mathrm{E}$ for $\mathrm{L}=1$ ) in lambs (2A) and growing cattle (2B) (same legend as in fig. 1 above).

decreases from 4 to 2.5 per cent units in lambs and from 3 to 1 per cent units in growing cattle fed mixed diets containing from 20 to 80 per cent concentrate. This can explain why BLAXTER et al. (1966) did not observe any significant variation in $\mathrm{dE}$ with $\mathrm{L}$ in growing steers fed a 50 per cent concentrate diet. However, the reduction in $\mathrm{dE}$ amounts to about 5 per cent units for diets based on maize silage and concentrates (TYRRELL et al., 1974).

\section{B) Methane production}

Methane energy losses (GE), expressed in per cent of gross energy intake (IE), are generally lower in growing ruminants than in adult sheep and they increase with age (Figure 3) (Demchenko, 1969 ; GraHAM and Searle, 1972 ; NeERGAARD, 1974 ; JENTSCH et al., 1976 ; WeBster et al., 1977 ; VERMOREL et al., 1980). In addition, GE decreases by about 1 per cent unit when the feeding level increases $(\mathrm{L}=1$ ) (Bouvier and Vermorel, 1975 ; Vermorel et al., 1980). The decrease is even greater in the case of compensatory growth in lambs 
(Thomson, 1979). However, Blaxter et al. (1966) did not observe significant variations in GE with age and feeding level, in growing steers between 15 and 81 weeks of age and the values equalled those expected for adult sheep. Similar results were obtained between 5 month-old lambs and adult sheep by BouviER and Vermorel (1975).

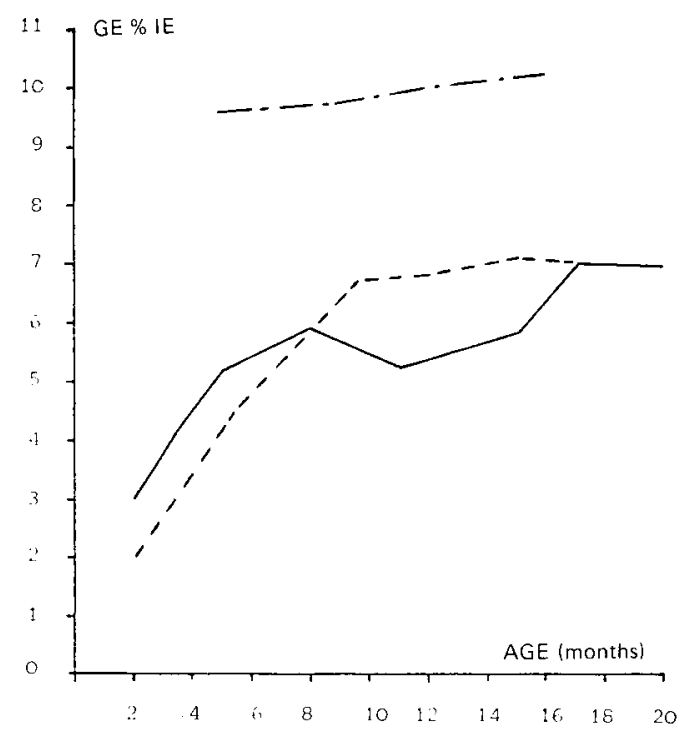

FIG. 3. - Variations of methane energy losses (GE \% IE)

in growing cattle with age: DEMCHENKo, 1969) (-); JENTSCH et al., 1976

in growing bulls (-..-) and adult sheep (-. -) fed the same diets.

The GE variations can be related to rumen development and to rumen fermentations, as well as to the molar proportions of volatile fatty acids in the rumen liquor : the normal working of the rumen seems to be reached in $175 \mathrm{~kg}$ bulls when fed diets with 22 per cent crude fibre but at more than $250 \mathrm{~kg}$ liveweight when the animals are fed diets with only 10 per cent crude fibre (SCHIEMANN et al., 1976).

Urinary energy depends mostly on urea excretion. Therefore, on the one hand, urinary energy losses (UE) increase with the protein level of the diet and, on the other hand, they are lower in growing than in adult ruminants : 3.3 versus 4.8 per cent of IE in growing bulls and adult sheep respectively for 44 diets (JENTSCH et al., 1976). Furthermore, UE increases with age : 2.9 and 3.7 per cent of IE in 10 week - and 8 month old bulls respectively (VERMOREL et al., 1980). However, when the protein gain of the growing animals is low, urinary energy losses are not significantly less than in adult ruminants (BLAXTER et al., 1966 ; Bouvier and Vermorel, 1975). In addition, UE decreases when the feeding level increases ; it amounted to 4.2 and 3.1 per cent of IE in lambs for $\mathrm{L}=1.3$ and 2.1 respectively (VERMOREL et al., 1980).

\section{Energy metabolisability}

Due to smaller methane and urinary energy losses, the ratio between metabolisable and digestible energy (ME/DE) is generally much higher in 


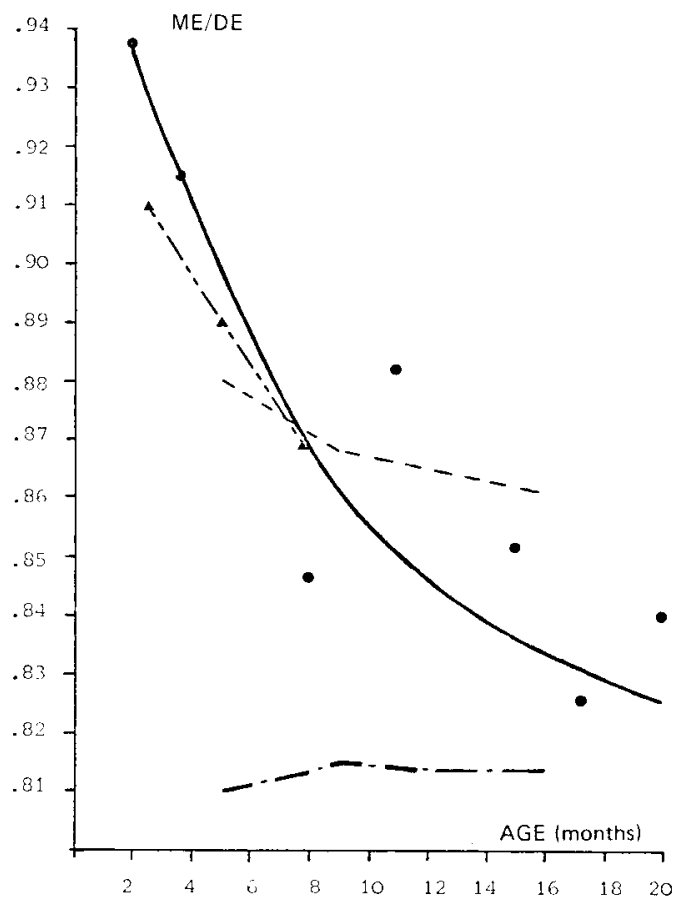

FIG. 4. - Variations of the ratio $M E / D E$ with age in growing cattle

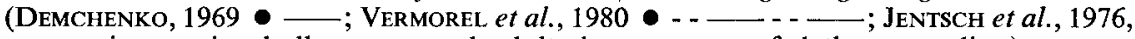
in growing bulls ..... and adult sheep - . . fed the same diets).

growing (about 0.87 ; i.e. from 0.82 to 0.93 ) than in adult ruminants $(0.81)$ (DemchenKo, 1969 ; Tyrrell et al., 1974 ; SChiemann et al., 1976 ; Webster et al., 1976 ; VeRMOREL et al., 1976, 1980), but the reduction still cannot be given accurately when the growing ruminants get older (Figure 4). The ratio $\mathrm{ME} / \mathrm{DE}$ also depends on the chemical and physical composition of the diet and on the feeding level (Figure 5) (Vermorel et al., 1980).

Therefore, to estimate the ME intake of growing ruminants from their DE intake measured at any feeding level, the mean coefficient 0.81 determined in adult ruminants at the maintenance feeding level should be avoided. The resulting error can reach 10 or 15 per cent and lead to large over-estimation of $\mathrm{ME}$ efficiency for growth in experiments using the slaughter technique. When necessary, it is better to estimate the ME intake of growing ruminants from the energy metabolisability of the diet determined in adult sheep. The data available show indeed that there is no significant difference in the feed energy metabolisability $(q)$ between growing and adult ruminants, at least for the same feeding level (JENTSCH et al., 1976 ; Vermorel et al., 1980). In the Rostock data obtained on 44 diets, the lower energy digestibility is compensated for by lower methane and urinary energy losses ; however $q$ is slightly higher in young bulls than in adult sheep (Figure 6). Furthermore, as shown by SchiEmanN et al., (1971) in the dairy cow, $q$ seems to decrease (by 1.9 per cent units) when $\mathrm{L}$ increases by one unit (VERMOREL et al., 1980). Webster et al., (1976) however, did not observe any significant variation in $q$ with $\mathrm{L}$. 


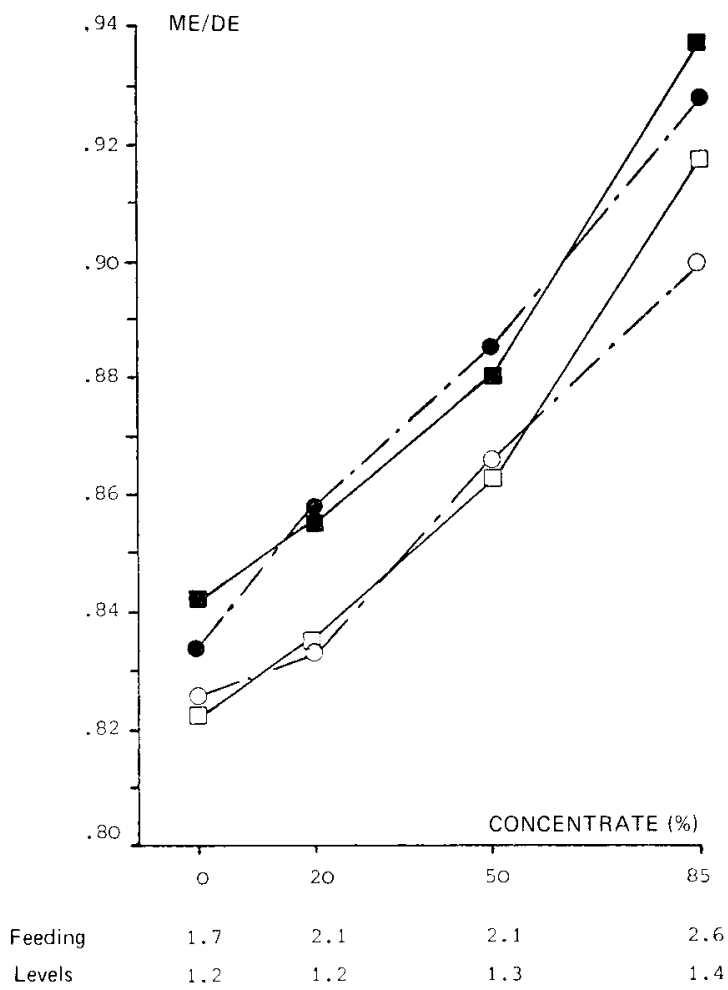

FIG. 5. - Variations of the ratio $M E / D E$ with diet composition and feeding level in growing lambs

So, in spite of the variability of the results obtained for digestibility, methane and urinary energy losses, it seems that the ME values of feeds determined in adult sheep can be used to calculate rations for growing ruminants, at least for the same feeding level.

\section{2. - Utilisation of metabolisable energy for maintenance and growth}

To determine feeding standards, the factorial approach is often employed. However, in doing this, one must be aware that requirements can hardly be separated, especially in the case of growing animals, as stressed by VAN Es (1980). Nevertheless, partial efficiencies of ME utilisation are most commonly computed separately using linear regression analysis for both maintenance $\left(k_{m}\right)$ and growth $\left(k_{g}\right)$ respectively (VAN ES, 1980).

\section{A. - Utilisation of $M E$ for maintenance}

From the early experiments of KELLner (1908) with adult steers it can be demonstrated that the efficiency of utilisation of digested starch is about 


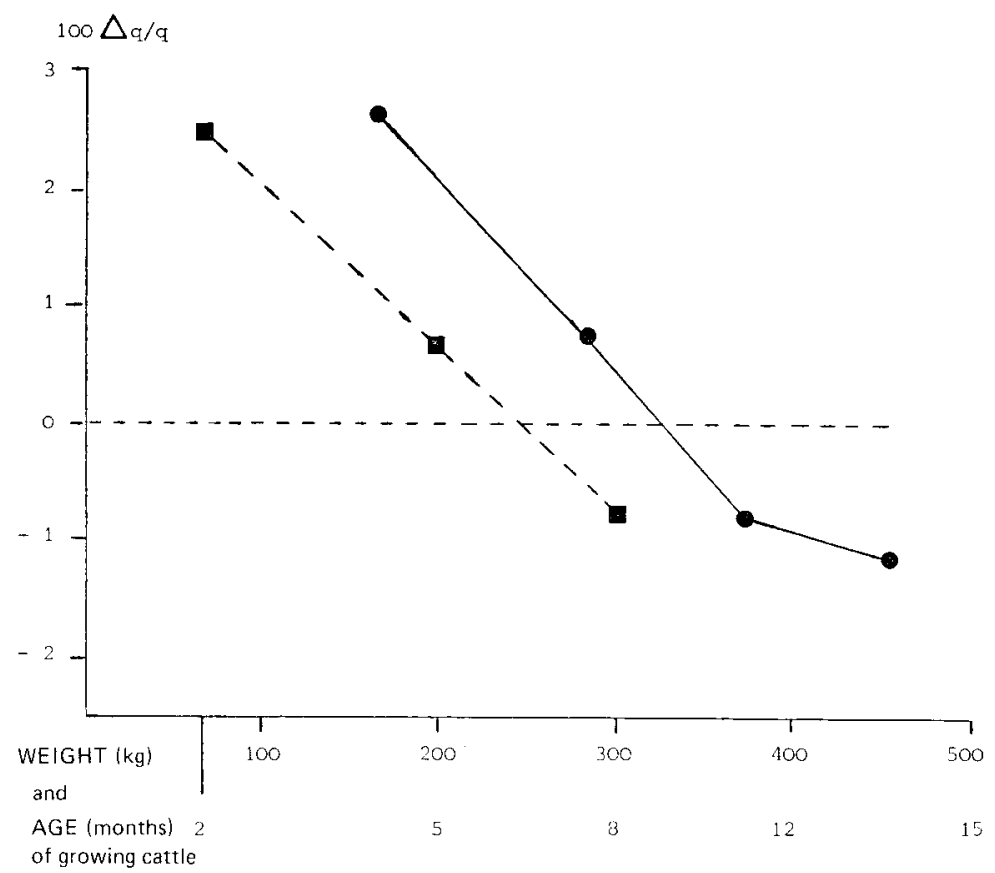

FIG. 6. - Difference in energy metabolisability $(100 \Delta q / q)$ between growing cattle and adult sheep; variations with age JENTSCH et al., 1976.

VerMOREL et al., 1980.

20 per cent higher for maintenance than for fattening. In the "Starch Equivalent" system for feed evaluation and feeding standards this result is extended to all feeds used in practical feeding. The principe of a better utilisation of energy for maintenance than for fattening was confirmed by BLAXTER (1962) and generally accepted, e.g. in the different new proposals for energy evaluation of feed and feeding standards (ARC, 1965 ; LofgreEN and GARRETT, 1968 ; VAN Es et al., 1978).

Calculation of $k_{m}$ stems from energy balances obtained by calorimetry with animals at maintenance or far below maintenance, including at fasting. Under these conditions growth is retarded and metabolism may change from the previous period of positive energy balance. However positive protein balance can be obtained in spite of a zero or slight negative energy balance and at the cost of negative fat balance (GingInS, 1978; THOMSON, 1979).

Retarding the growth by underfeeding the animals showed a substantial reduction in maintenance heat production (MHP) or ME requirement $(\mathrm{MEm})$ of growing calves (THORBEK and HencKel, 1976) growing steers (CRABTrEe et al., 1976 ; SCHNYDER, 1979) growing heifers (TyrRell and MoE, 1980) and growing bulls (Vermorel et al., 1980), as of growing pigs (GraY and MC CRACKEN, 1980). In these experiments, MHP was reduced by 60 to $100 \mathrm{~kJ} / \mathrm{kg}$ $\mathrm{W}^{\frac{3}{2}}$. Similar results were obtained with adult sheep when the feeding level was altered from the maintenance level to an underfed level (Table 1 and Figure 7) (GINGINS, 1978). 
TABLE 1

FASTING HEAT PRODUCTION (FHP), ME REQUIREMENT FOR MAINTENANCE (MEm) AND PARTIAL EFFICIENCY OF ME UTILISATION FOR MAINTENANCE $\left(k_{m}\right)$ AT MAINTENANCE OR DURING UNDERFEEDING AND REALIMENTATION OF ADULT SHEEP (GINGINS, 1978)

\begin{tabular}{|c|c|c|c|c|}
\hline Feeding level & $\begin{array}{c}\operatorname{FHP}(1) \\
\left(\mathrm{kJ} / \mathrm{w}^{3 / 4}\right)\end{array}$ & $\begin{array}{c}\text { MEm } \\
\left(\mathrm{kJ} / \mathrm{w}^{3 / 4}\right)\end{array}$ & $\mathrm{k}_{\mathrm{m}}(3)$ & $\begin{array}{l}\text { 'True ' } \\
k_{m} \text { (3) }\end{array}$ \\
\hline Maintenance & 279 & $381^{(1)}$ & 0.73 & \\
\hline Underfeeding & 249 & $275^{(2)}$ & 0.91 & 0.75 \\
\hline Realimentation & 293 & $374^{(2)}$ & 0.78 & \\
\hline
\end{tabular}

(1) Measured FHP or MEm

(2) MEm estimated by regression analysis

(3) $\mathrm{k}_{\mathrm{m}}$ calculated as FHP/MEm

(4) 'True' $\mathrm{k}_{\mathrm{m}}$ ' estimated by regression analysis

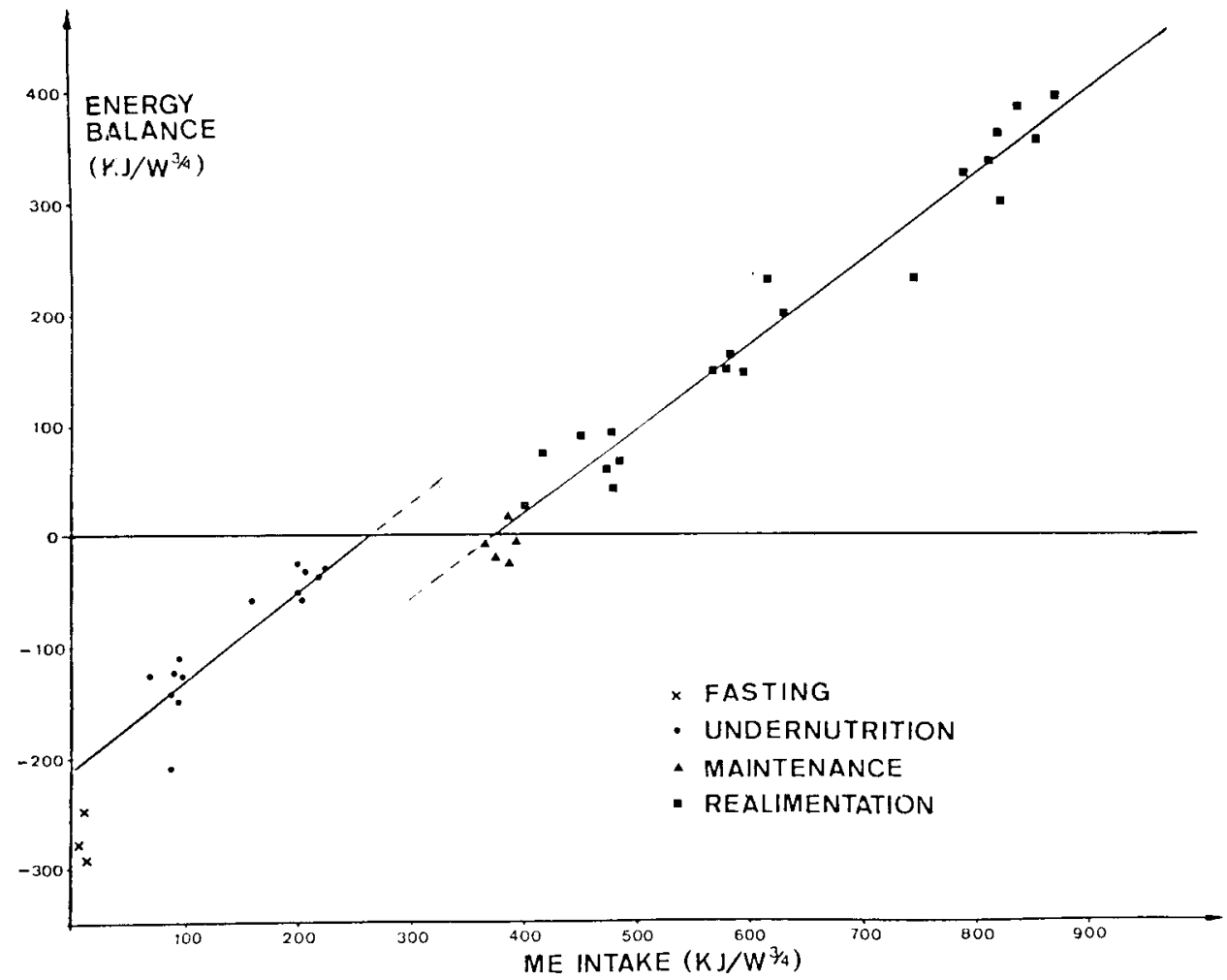

FIG. 7. - Energy balances of adult sheep at fast or maintenance, during undernutrition or realimentation (GINGINS, 1978).

Undernutrition: $\quad \mathrm{EB}=-206+0.75 \mathrm{ME} \quad \mathbf{R}^{2}=\mathbf{0 . 8 0}$

Realimentation: $\quad \mathrm{EB}=-273+0.73 \mathrm{ME} \quad \mathrm{R}^{2}=0.95$ 
From these results, it appears that not only FHP and MEm, but also $k_{m}$ could be influenced by the feeding level. However, if statistical regression analysis is used to determine " true " $k_{m}$ for the underfed animals, without including the FHP, the value (0.75) is comparable to those given by ARC (1965), MAFF (1975) and VAN Es (1978) (fig. 7). Yet, if FHP is included in the regression computation, a non-linear regression line would better suit the results than a linear regression line. This suggests that a drastic change in the energy metabolism takes place at fasting.

Steers of various breeds are able to maintain different liveweights at the same feed intake (VERCOE, 1970). The discrepancy is not necessarily and only due to differences in fasting metabolism; it may also come from a better efficiency of $\mathrm{ME}$ utilisation for maintenance (VERCOE, 1970). Between Hereford $\times$ Shorthorn (HS) and Brahman $\times$ HS steers, the difference may amount to 10 per cent (VerCOE, 1970; VerCOE and FrISCH, 1974; FrISCH and VerCOE, 1976). According to these authors, the higher $k_{m}$ in Brahman $\times$ HS steers could be due to a lower methane production and smaller proportion of acetic and butyric acids in the rumen volatile fatty acids, but probably not to differences in body composition.

\section{B. - Energy utilisation for growth}

Knowledge of the efficiency of ME utilisation by growing ruminants is still poor compared to that obtained on monogastric animals. The number of studies is limited and the results are often conflicting. The discrepancies may originate, on the one hand, in the variability of feeds and rations used and, on the other hand, in the diversity of genetic types and physiological stages of experimental animals. They are likely to come from poor estimates of $\mathrm{ME}$ intake and maintenance requirements, which sometimes are not determined in these experiments. The main reason, however, is probably the lack of accuracy in measuring energy retention (especially by calorimetry) which amounts only to 10 or 25 per cent of energy intake in lambs and 5 to 15 per cent in growing bulls. Therefore, the results obtained with very low weight gains are hardly reliable.

\section{$M E$ utilisation for protein and lipid deposition}

The studies carried out on growing monogastric animals have shown that the efficiency of ME utilisation is lower for growth $\left(k_{g}\right)$ than for fattening $\left(k_{f}\right)$ (cf. reviews by Kielanowski, 1976, and THORBEK, 1977). The difference comes from the higher energy expenditure associated with protein deposition. In the statistical models mentioned and criticised by VAN Es (1980) this is expressed as a lower efficiency of ME utilisation for protein $\left(k_{p r}\right)$ than for lipid $\left(k_{l p}\right)$ deposition (about 45 and 75 per cent respectively), mainly due to different biochemical pathways and to a high protein turnover (EDMUNDS et al., 1980).

A similar trend was obtained in growing ruminants but the data are scarce and very variable. Some figures derived for $k_{p r}$ and $k_{l p}$ are irrelevant for the reasons indicated above and because protein gain and lipid gain are not independent variates and the variation range of protein gain is not large enough to allow an accurate estimate of $k_{p r}$. The results obtained on growing lambs seem to indicate that $k_{p r}$ is about 33 per cent and $k_{l p} 70$ per cent (from 55 to 99 per cent, øRSKOV and McDonald, 1970, 1976; Bickel and Durrer, 1974; Thomson, 1979; Theriez et al., 1980). However, much lower values were obtained for $k_{p r}$ by FERRELL et al. 
(1979) and RatTray and JoYCE (1976) but in this case, the weight gains of the lambs were very low.

Furthermore, from a large number of balances carried out on growing bulls, by indirect calorimetry, SCHIEMANN et al. (1976) concluded that $k_{p r} / k_{l p}$ was about $1 / 1.9$, that is, a figure similar to that obtained in monogastric animals. Using the comparative slaughter technique in growing Limousin bulls, RoBELIN and GEAY (1976) showed that $k_{g}$ increased with the proportion of energy retained as fat. Finally, in feeding trials on growing finishing bulls of different French breeds and cross-breeds, Colleau (1978), using the slaughter technique, obtained figures of 33 per cent for $k_{p r}$ and 55 per cent for $k_{l p}$.

So, in ruminants as in monogastric animals, the efficiency of ME utilisation for growth seems to depend on the proportions of energy retained as protein and lipids. It is, therefore, important to examine the effect on $k_{g}$ of factors which can influence the composition of body gain.

\section{Effect of age}

Several experiments carried out on lambs and growing bulls or steers have shown that $k_{g}$ was lower than the $k_{f}$ value expected for adult ruminants (WEBSTER et al., 1974; GeAY et al., 1976; Robelin and GEAY, 1976; FERrell et al., 1979; GeaY et al., 1980; Thomson and Cammell, 1979, 1980). However, for a wide range of diets, HoFFMANN et al. (1977) obtained, on average, the same maintenance requirements and similar ME efficiencies for growth $\left(k_{g}=58\right.$ per cent $)$ in bulls and for fattening $\left(k_{f}=55\right.$ per cent) in adult steers. In the same way, Bouvier and VERMOREL (1975) did not observe any significant difference in ME efficiency for the same diet fed to 4 month-old lambs and adult sheep, whereas the proportion of energy retained as fat (FE) amounted to 70 and 85 per cent of energy gain respectively, but the maintenance requirement was much higher in the lambs. WEBSTER et al. (1972) concluded likewise from an experiment on lambs only.

As the animals get older, the proportion of energy retained as fat increases and consequently $k_{g}$ should rise. However, it did not vary significantly in growing steers between 15 and 81 weeks of age, but FE increased only from 70 to 75 per cent (BLAXTER et al., 1966). In the same way, $k_{g}$ determined by the comparative slaughter technique in Limousin bulls did not increase significantly over 3 growth periods (9-13, 13-16 and 16-19 months of age), although FE increase from 46 to 70 per cent, but the results were very variable $\left(0.29 \leqslant \mathrm{k}_{g} \leqslant 0.48\right.$ ) (RoBELIN and GEAY, 1976). So, the actual phenomena can be masked by the lack of accuracy in the measurements, the variability of the results and inadequate estimates of maintenance requirements.

\section{Effect of breed}

Available data are also scarce. In growing steers the efficiency of ME utilisation for body gain was better in Herefords, which had a higher fat gain, than in Holsteins (GARRETT, 1971). In experiments on growing fattening bulls of different French breeds and crossbreeds, ColleAu (1978) obtained only small variations in $k_{g}$ (49.8 per cent for the Holstein $\times$ Friesian and 46.8 per cent for the Charolais) in spite of rather large variations in FE (74.5 and 62.3 per cent respectively). There were, however, large differences in maintenance requirements $\left(636 \mathrm{~kJ} / \mathrm{kg} \mathrm{W}^{0.75}\right.$ for 
the HF and 552 for the Charolais bulls). In the same way, Vermorel et al. (1976) did not observe significant differences in $\mathrm{k}_{q}$ between Friesian and Charolais calves or bulls, in spite of large variations in $\mathrm{FE}$, but a 13 per cent lower maintenance requirement for the Charolais bulls.

\section{Effect of sex}

The efficiency of ME utilisation for growth seems to be higher (by about 5 to 8 per cent units) in females than in intact males, which may be connected with the higher proportion of energy retained as fat, in sheep (Bull et al., 1976; Ferrell et al., 1979; THERIEZ et al., 1980) and in cattle (GEAY et al., 1980) (Table 2). However, $k_{g}$ seems to be similar in heifers and in castrated steers (GARRETT, 1970, 1980).

TABLE 2

EFFICIENCY OF ME UTILISATION FOR GROWTH. EFFECT OF SEX IN CONNECTION WITH THE PROPORTION OF ENERGY RETAINED AS FAT (FE)

\begin{tabular}{|c|c|c|c|c|c|c|}
\hline \multirow{2}{*}{ Animals } & & & \multicolumn{2}{|c|}{$E E$} & \multirow{2}{*}{ References } \\
\hline & & & & & & \\
\hline \multicolumn{2}{|l|}{ Lambs } & .58 & .66 & $82 \%$ & 898 & $\begin{array}{l}\text { Bull, Tyrrell and Reid, } \\
1976\end{array}$ \\
\hline \multicolumn{2}{|l|}{ Lambs } & .31 & .36 & $74 \%$ & $82 \%$ & Ferrell et al., 1979 \\
\hline \multirow{2}{*}{ Lambs } & (1) & .27 & .33 & 648 & 758 & Theriez, Houssin and \\
\hline & $(2)$ & .42 & .48 & $67 \%$ & 798 & Castillo Gonzales, 1980 \\
\hline \multirow{2}{*}{ Cattle } & (3) & .24 & .31 & $50 \%$ & 628 & Geay, Robelin and \\
\hline & (4) & .32 & .42 & $62 \%$ & $79 \%$ & Vermorel, 1980 \\
\hline
\end{tabular}

Diet composition: dehydrated lucerne: (1) $70 \%$; (2) $30 \%$; (3) $80 \%$;

(4) $20 \%$ and concentrate

\section{Effects of feeding level and diet composition}

In the experiments carried out on different feeding levels (L), the efficiency of ME utilisation for growth did not vary significantly with L (THORBEK and HENCKel, 1976; GeAY et al., 1976; THERIEZ et al., 1980; VeRMOREL et al., 1980).

From the energy balances obtained on adult ruminants, BLAXTER (1974) showed that $k_{f}$ increased with the metabolisability of the diet $(q)$ and he obtained several equations for different types of diets. In growing ruminants, $k_{g}$ seems to vary also with $q$, although WeBSTER (1976) obtained the same value (62 per cent) for 2 diets with different $q$ values $(0.55$ and 0.67$)$. However, the slope of the regression line of $k_{g}$ over $q$ seems to be lower in growing ruminants than in adults (FERRELL et al., 1979; Geay et al., 1980; Thomson and Cammell, 1980; Vermorel et al., 1980).

Furthermore, some data obtained on growing heifers and steers by GARRETT 
(1980) and on growing bulls and heifers by GEAY et al. (1980) seem to show that the ratio between $k_{g}$ and $k_{f}$ (according to BLAXTER (1974) equation) is almost constant for a given type of growing cattle for $0.50 \leqslant q \leqslant 0.70$ (Table 3 ). These results must be confirmed. However, as feeds have about the same ME content in growing and adult ruminants, this would mean that, if their net energy values for growth or fattening are different, the relative energy values of feeds are similar. So, $k_{f}$ could be used instead of $k_{g}$, with little error, to calculate the energy value (expressed in Feed Units) of feeds for growing ruminants. This assumption was adopted in the new Dutch, French and Swiss energy systems for beef cattle (VAN Es et al., 1978).
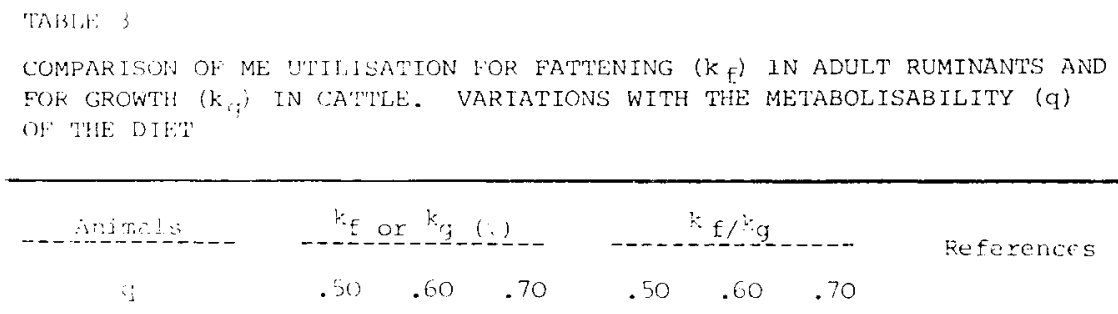

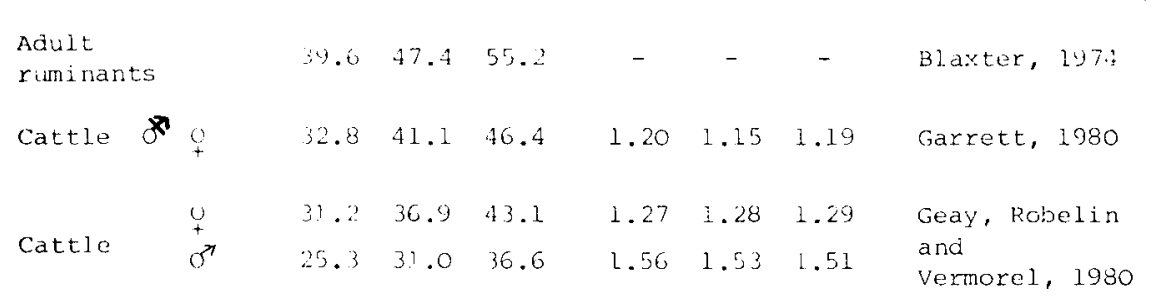

\section{3. - Total efficiency of energy utilisation for growth}

From a practical point of view, the total efficiency of energy utilisation for growth $\left(k_{t}\right)$ is an important criterion because it is the main factor of feed efficiency. $k_{t}$ is defined as the ratio of retained energy (RE) over the total intake of gross energy (IE) or ME. It depends on the feeding level (L) and on the partial efficiency of energy utilisation for growth $\left(k_{g}\right.$. if referred to $\left.\mathrm{ME}\right)$, with the following relationship (BICKEL, 1977).

$$
\mathrm{RE}=k_{g}(\mathrm{ME}-\mathrm{MEm}) \quad \mathrm{RE}=k_{g}\left(1-\frac{1}{\mathrm{~L}}\right) \mathrm{ME} \quad k_{t}=k_{g}\left(1-\frac{1}{\mathrm{~L}}\right)
$$

This hyperbolic function shows the diminishing increase in $k_{t}$ as $\mathrm{L}$ rises. If $k_{g}$ is assumed to increase linearly (as FE increases) or asymptotically with $\mathrm{L}, k_{t}$ is maximum and reaches $k_{g}$ when $\mathrm{L}$ is infinite (fig. 8). However, if $k_{g}$ varies curvilinearly and decreases with high feeding levels, then $k_{t}$ reaches a maximum value in the finite range of $\mathbf{L}$ (fig. 8).

The feed conversion ratio (FCR) is also theoretically a hyperbolic function of L. If $c_{g}$ and $c_{f}$ are the energy concentrations of gain and feed (expressed by ME), FCR can be expressed with the following relationship:

$$
\mathrm{FCR}=\frac{\mathrm{ME} / c_{j}}{\mathrm{RE} / c_{g}}=\frac{c_{g}}{c_{f}} \times \frac{\mathrm{ME}}{k_{g}\left(1-\frac{1}{\mathrm{~L}}\right) \mathrm{ME}} \quad \mathrm{FCR}=\frac{1}{k_{g}} \times \frac{c_{g}}{c_{f}} \times \frac{\mathrm{L}}{\mathrm{L}-1}
$$




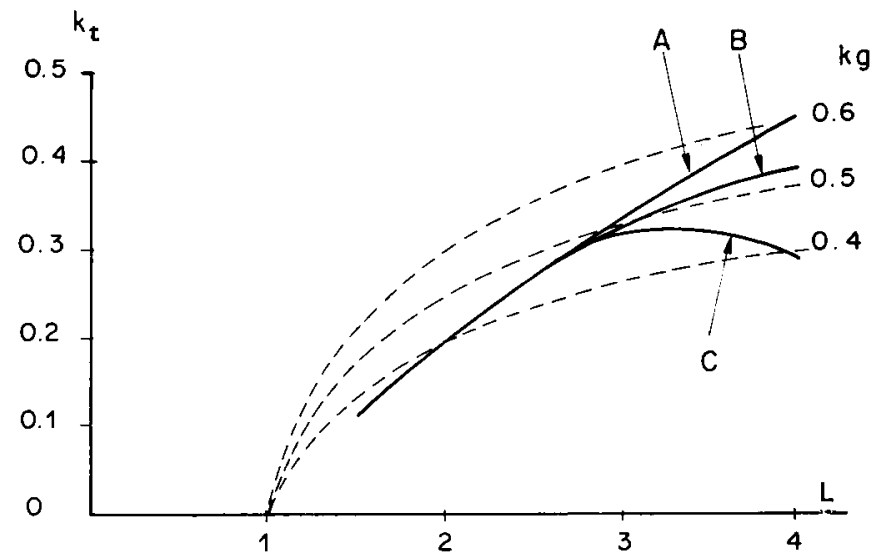

FIG. 8. - Relationship between total efficiency $\left(k_{t}\right)$, partial efficiency $\left(k_{g}\right)$ of energy utilisation for growth and feeding level (L.).

\section{- . . . - variation of $k_{t}$ for a given value of $k_{0}$.}

variation of $k_{t}$ when $k_{g}$ increases linearly (A) or asymptotically (B) with $\mathrm{L}$ or varies curvilinearly and decreases for high feeding levels (C).

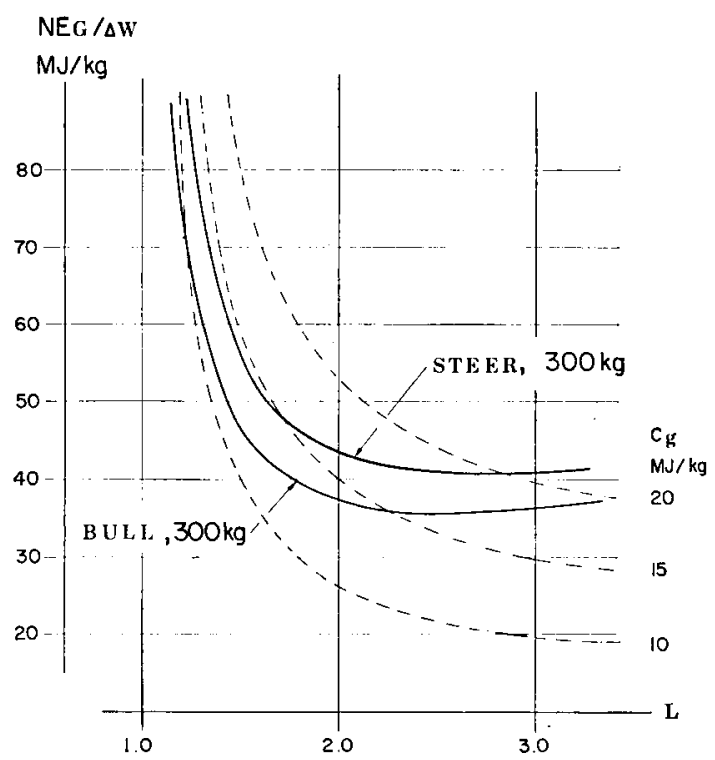

FIG. 9. - Relationship between energy conversion ratio, feeding level (L)

and energy value of gain $\left(c_{g}\right)$. Example for fattening bull and steer (Swiss dual purpose breed) (cf text).

(Energy conversion ratio: net energy for growth per $\mathrm{kg}$ weight gain)

..... when $c_{g}$ is constant.

when $c_{g}$ increases with $\mathrm{L}$. 
However, $c_{g}$ is not a constant, but it increases with L. Therefore, FCR reaches a minimum value in the finite range of $\mathrm{L}$. This holds true also for the energy conversion ratio (ECR), defined as the requirement of net energy for growth (NEG) per $\mathrm{kg}$ liveweight gain. Figure 9 shows an example of the variations of NEG with $\mathrm{L}$ for bulls and steers at $300 \mathrm{~kg}$ liveweight. The dotted lines represent the theoretical hyperbolic functions for 3 different values of $c_{g}$. The calculation is based on the estimation of $c_{g}$ from experimental results with Swiss dual purpose cattle (LeHMANN, 1979). No correction of $\mathrm{k}_{g}$ was made for the influence of the protein level. It is suggested that this influence is of minor importance compared to the influence of $\mathrm{L}$ and $c_{g}$.

The example shows that FCR may be optimised for any specific case, if the relationship between level of feeding and energy value of gain is known.

\section{Conclusion}

In growing ruminants, $\mathrm{ME}$ intake and the $\mathrm{ME}$ content of feeds can be estimated accurately, in spite of variations in energy digestibility, in methane and urinary energy losses. The estimates of energy, protein and fat gain are less accurate, especially when using calorimetry. However, the partition of the total heat production $(\mathrm{H}=\mathrm{ME}-\mathrm{RE}$ ) into its various components is tricky.

$\mathrm{H}$ amounts to about 50 per cent of $\mathrm{IE}$ and ranges from 60 to 90 per cent $\mathrm{ME}$ intake ; it depends firstly on the breed, sex, age, physical activity and body gain composition of the animals, and secondly, on the diet composition and $\mathrm{ME}$ intake. The heat production arises from numerous interrelated phenomena which set the metabolic rate in different tissues and organs : maintenance of the cellular structure and activity, protein and lipid synthesis associated with different turn-over rates. Therefore, the partition of this energy expenditure between maintenance and tissue gains leads to various conclusions depending on the methods used, the accuracy of the estimates and the statistical model used to analyse the data.

These phenomena can be analysed properly only if ME and RE are determined very accurately, if the variations in protein gain and fat gain are large and if the other factors which can influence the metabolic rate are mastered. With such an analysis the energy allowances which promote the best efficiency for each kind of ruminant and a given production type can be defined.

\section{References}

Agricultural ReSEARCH COUncil, 1965. The Nutrient Requirement of Farm Animals, (ARC), 2, Ruminants (Agricultural Research Council, London).

Bickel H., 1977. Der Futteraufwand in der Rindviehproduktion unter besonderer Berucksichtigung des Wirkungsgrades der Energieverwertung. Schw. Landw. Fo., 16, 175 .

Bickel H., Durrer A., 1974. Energy utilisation by growing sheep. Proc. 6th Symp. Energy Metab., 119-122, EEAP $\mathrm{N}^{\circ}$ 14, MENke, K.H. (Ed.), Stuttgart (BRD).

BLAXTER K.L., 1962. The energy metabolism of ruminants. Hutchinson, London, $329 \mathrm{pp.}$

Blaxter K.L., 1974. Metabolisable energy and feeding systems for ruminants. In : $H$. Swan and D. Lewis (Ed.), Proc. Nutr. Conf. Feed Manuf., Nottingham. Butterworths, London, 3-25.

Blaxter K.L., Clapperton J.L., Wainman F.W., 1966. Utilisation of the energy and protein of the same diet by cattle of different ages. J. Agric. Sci., Camb., 67, 67-75. 
Bouvier J.C., Vermorel M., 1975. Utilisation énergétique et azotée d'une même ration par le Mouton adulte à l'engraissement et l'Agneau en croissance. Ann. Zootech., 24 (4), 697-710.

Bull L.S., Tyrrell H.F., ReId J.T., 1976. Energy utilisation by growing male and female sheep and rats, by comparative slaughter and respiration techniques. Proc Symp. Energy Metabolism of Farm Animals, 137-140. M. Vermorel (Ed.) G. DE BuSSAC, Clermont-Ferrand.

CARle B., 1970. (Personal communication).

Colleau J.J., 1978. Analyse et décomposition de la variabilité intergénotypique de la consommation alimentaire pour des jeunes bovins. Ann. Génét. Sél. Anim. 10 (1), $29-45$.

Colovos N.F., Holter J.B., Koes R.M., Urban W.E., Davis H.A., 1970. Digestibility, nutritive value and intake of ensiled corn plant (Zea mays) in cattle and sheep. J. Anim. Sci., 30, 819-824.

Crabtree R.M., Kay M., Webster A.J.H., 1976. The net availabilities of metabolisable energy for body gain of two pelleted diets offered to Hereford $\mathrm{x}$ Friesian castrate males over different live-weight ranges. Anim. Prod., 22, 1, 156-157.

Demchenko P.V., 1969. Energy metabolism of growing cattle. Proc. 4th Symp. Energy Metabolism of Farm Animals, Warsaw, 213-219. K.L. Blaxter, J. KJelanowsKI and G. Thorbek (Ed.) Oriel Press Ltd, Newcastle.

Edmunds B.K., Butrery P.J., Fisher C., 1980. Protein and energy metabolism in the growing pig. Proc. 8th Symp. Energy Metabolism, Cambridge, L.E. Mount (Ed.), Butterworths, London.

Es A.J.H. VAN, 1978. Feed evaluation for Ruminants. I. The systems in use frem May 1977 onwards in the Netherlands. Livestock Prod. Sci., 5, 331-345.

Es A.J.H. VAN. 1980. Net requirements for maintenance as dependent on weight, feeding level, sex. and genotype, estimated from balance trials. Ann. Zootech., 29, $\mathrm{n}^{\circ}$ hors-série.

Es A.J.H. VAN, Vermorel M., Bickel H., 1978. Feed evaluation for ruminants : new energy systems in the Netherlands, France and Switzerland. General introduction. Livestock Prod. Sci., 5, 327-330

Ferrell C.L., Crouse J.D., Field R.A., Chant J.L., 1979. Effects of sex, diet and stage of' growth upon energy utilisation by lambs. J. Anim. Sci, 49, 3, 790-801.

Frisch J.E., VERCOE J.E., 1976. Maintenance requirement, fasting metabolism and body composition in different cattle breeds. Proc. 7th Symp. Energy Metabolism, Vichy, 209-212. M. Vermorel (Ed.) G. DE Bussac, Clermont-Ferrand.

GARRETT W.N., 1970. The influence of sex on the energy requirements of cattle for maintenance and growth. Proc. 5th Symp. Energy Metabolism of Farm Animals, Vitznau, 101-104. A. Schurch and C. Wenk (Ed.) Juris Druck + Verlag, Zürich.

GarretT W.N., 1971. Energetic efficiency of beef and dairy steers. J. Anim. Sci., 32, 3, 451-456.

GaRRET W.N., 1980. Energy utilisation by growing animals as determined in seventy-two comparative slaughter experiments. Proc. 8th Symp. Energy Metabolisn, Cambridge, L.E. Mount (Ed.) Butterworths, London.

Geay Y., Robelin J., Jarrige R., 1976. The influence of the metabolisable energy content of the diet on the efficiency of energy utilisation by young fattening bulls. Proc. $7 \mathrm{th}$ Symp. Energy Metabolism of Farm Animals, Vichy, 225-228. M. Vermorel (Ed.) G. DE Bussac, Clermont-Ferrand.

Geay Y., Robelin J., Vermorel M., 1980. Influence of the metabolisable energy content of the diet on energy utilisation for growth in bulls and heifers. Proc. 8th Symp. Energy Metabolism, Cambridge, L.E. Mount (Ed) Butterworths, London.

Gingins M., 1978. Efficience du processus de pertes et de récupération de poids chez le ruminant adulte. Thèse ETH No. 6228, 79 pp.

Graham N. Mc. Searle T.W., 1972. Balances of energy and matter in growing sheep at several ages, body weight, and planes of nutrition. Aust. J. Agric. Res., 23, 97-108.

Gray R., McCracken K.J., 1980. Plane of nutrition and the maintenance requirement. Proc. 8th Symp. Energy Metabolism, Cambridge, L.E. Mount (Ed.), Butterworths, London.

Hoffmann L., Jentsch W., Schiemann R., 1977. Die Verwertung der Futterenergie durch wachsende Bullen. Arch. Tierernahr., 27, 545-562.

Jentsch W., Wittenburg H., SchiemanN R., 1976. Die Ververtung der Futterenergie durch wachsende Bullen. Arch. Tierernahr, 26, 575-585. 
Kielanowski J., 1976. Energy cost of protein deposition. Proc. 1st Symp. on Protein Metabolism and Nutrition, Nottingham, 1974, 207-215. D.J.A. Cole et al. (Ed) Butterworths, London.

Kellner O., 1908. Grundzüge der Fütterrungslehre, Parey, Berlin.

LeHMANN E., 1979. In : SCHNEEBERger H. (Ed), Futterungsnormen und Nahrwerttabellen für Wiederkauer, LMZ, Zollikofen $(\mathrm{CH})$.

Le Neindre P., $1980 . \quad$ (Personal communication).

LOFGREEN G.P., GarRetT W.N., 1968. A system for expressing net energy requirement and feed values for growing and finishinig beef cattle. J. Anim. Sci., 27, 3, 793-806.

MAFF 1975. Energy allowances and feeding systems for ruminants. Technical Bulletin 33, HMSO, London.

NeErGaARd L., 1974. Methane production in growing calves in relation to the composition of the food. Proc. 6th Symp. Energy Metabolism of Farm Animals, Hohenheim, 103-106. K.H. Menke, H.J. Lantsch and J.L. Reichl (Ed.) Universitat Hohenheim, Dokumentationsstelle.

Noot C.W., VAN Der, Cordts R.H., Hunt R., 1965. Comparative nutrient digestibility of silages by cattle and sheep. J. Anim. sci., 24, 47-50.

ORSKOV E.R., MCDONALD I., 1970. The utilisation of dietary energy for maintenance and for fat and protein deposition in young growing sheep. Proc. 5th Symp. Energy Metab., Witznau, 121-124, A. Church and C. WeNk (Ed.) Juris Durck + Verlag (Zürich).

Orskov E.R., MCDonald I., 1976. The effects of changing from a low to a high protein diet on growth, body composition and energy utilisation by lambs. Proc. 7 th Symp. Energy Metabolism of Farm Animals, Vichy, 133-136, M. Vermorel (Ed.), G. DE Bussac, Clermont-Ferrand.

Preston T.R., Archibald J.D.H., Tinkler W., 1957. The digestibility of grass by young calves. J. Agric. Sci., 48, 259-265.

RATTRAY P.V., JOYCE J.P., 1976. Utilisation of metabolisable energy for fat and protein deposition ini sheep. N.Z. J. Agric. Res., 19, 299-305.

RaYMond W.F., Harris C.E., KeMP C.D., 1975. 4. Studies in the digestibility of herbage. 5. The variation, with age of the ability of sheep to digest herbage, with observations on the effect of season on digestive ability. J. Brit. Grassland Soc., 9, 209-220.

Robelin J., GeaY Y., 1976. Changes with age $(9,13,16,19$ months) of protein and energy retention and energy utilisation by growing Limousin bulls. Proc. 7th Symp. Energy Metabolism of Farm Animals, Vichy, 213-216. M. Vermorel (Ed.) G. DE BussaC, Clermont-Ferrand.

Schiemann R., Jentsch W., Wittennurg H., 1971. Zür Abhangigkeit der Verdaulichkeit der Energie und der Nahrstoffe von der Höhe der Futterraufnahme und der Rationszusammensetzung bei Milchkühen. Arch. Tierernahr., 21, 223-240.

Schiemann R., Jentsch W., Wittenburg H., Hoffmann L., 1976. Die Verwertung der Futterenergie durch wachsende Bullen. Arch. Tierenahr., 26, 491-517.

SCHNYDER, 1979. (Personal communication).

Theriez M., Houssin Y., Castillo-Gonzales, 1980. (Personal communication).

Theriez M.. Tissier M., Brun J.P., 1980. Effects of metabolisable energy content of diet and feeding level on the efficiency of energy utilisation by growing lambs. Proc. 8th Symp. Energy Metabolism, Cambridge, L.E. Mount (Ed.), Butterworths, London.

Thомson E.F., 1979. Energy metabolism of sheep and cattle during compensatory growth. Diss. ETH No. 6382,112 pp.

Thomson D.J., Cammell S.B., 1979. The utilisation of chopped and pelleted lucerne (Medicago sativa) by growing lambs. Br. J. Nutr., 41, (2), 297-310.

Thomson D.J., Cammell S.B., 1980. The evaluation of the energy in forage by the comparative slaughter technique. Proc. 8th Symp. Energy Metabolism, Cambridge, L.E. MounT (Ed.) Butterworths, London.

ThOrbek G., 1977. The energetics of protein deposition during growth. Nutr. Metab., 21, $105-118$.

Thorbek G., Henckel S., 1976. Studies on energy requirement for maintenance in farm animals. Proc. 7 th Symp. Energy Metabolism of Farm Animals, 117-120, M. Vermorel (Ed.) G. DE Bussac, Clermont-Ferrand.

Tyrrell H.F., MoE P.W., 1980. Energetics of growth in cattle. Proc. 8th Symp. Energy Metabolism, Cambridge, L.E. Mount (Ed.) Butterworths, London. 
Tyrrell H.F., Moe P.W., OltJen R.R., 1974. Energetics of growth and fattening compared to lactation in cattle. Proc. 6th Symp. on Energy Metabolism of Farm Animals, 205-208, K.H. Lantzsch and J.R. Reichl (Ed.), Universitat Hohenheim, Dokumentationsstelle.

VERCOE J.E., 1970. Fasting metabolism and heat increment of feeding in Brahman British and British cross cattle. Proc. 5th Symp. Energy Metaholism of Farm Animals, Vitznau, 85-88., A Schurch and C. Wenk (Ed.) Juris Druck + Verlag, Zürich.

VERCOE J.E., Frisch J.E., 1974. Fasting metabolism, liveweight and voluntary feed intake of different breeds of cattle. Proc. 6th Symp. Energy Metabolism of Farm Animals, 131-134, K.H. Menke, H.J. Lantzsch and J.R. ReICHL (Ed) Universitat Hohenheim, Dokumentationsstelle.

Vermorel M., Bouvier J.C., Geay Y., 1976. The effect of genotype (normal or double muscled Charolais and Friesian) on energy utilisation by growing cattle at 2 and 16 months of age. Proc. 7th Symp. on Energy Metabolism of Farm Animals, 217-220. M. Vermorel (Ed.) G. De Bussac, Clermont-Ferrand.

Vermorel M., Bouvier J.C., Geay Y., 1980. Energy utilisation by growing calves ; effects of age and milk intake. Proc. 8th Symp. on Energy Metabolism, Cambridge, L.E. Mount (Ed), Butterworths, London.

Webster A.J.F., Brockway J.H., Smith J.S., 1974. Prediction of the energy requirements for growt in beef cattle. 1. The irrelevance of fasting metabolism. Anim. Prod., 19, 27-139.

Webster A.J.F., Smith J.S., Crabtree R.M., Mollison G.S., 1976. Prediction of the energy requirements for growth in beef cattle. 2. Hereford $\mathrm{x}$ British Friesian steers given dried grass or barley. A nim. Prod., 23, 329-340.

Webster A.J.F., SMith J.S., Mollison G.S., 1977. Prediction of the energy requirements for growth in beef cattle. 3. Body weight and heat production in Hereford $x$ British Friesian bulls and steers. Anim. Prod., 24, 237-244. 